\title{
Body composition and nutritional requirements of protein and energy for body weight gain of lambs browsing in a tropical semiarid region ${ }^{1}$
}

\author{
Aderbal Marcos de Azevêdo Silva ${ }^{2}$, Ecileide Mamede dos Santos ${ }^{3}$, José Morais Pereira \\ Filho $^{3}$, Olaf Andreas Bakke ${ }^{2}$, Severino Gonzaga Neto ${ }^{4}$, Roberto Germano da Costa ${ }^{4}$
}

\author{
${ }^{1}$ Apoio financeiro: $C N P q$ \\ 2 UFCG-CSTR, Patos-PB \\ ${ }^{3}$ UFCG-CSTR, Av. Universitária s/n, Santa Cecília, CEP: 58.700-970, Patos-PB. \\ 4 Programa de Pós-Graduação em Zootecnia/UFPB-CCA, Areia-PB.
}

ABSTRACT - This study evaluated body fat, protein and energy contents and nutritional requirements for body weight (BW) gain of lambs in tropical semiarid conditions. Thirty-two castrated Santa Inês 3-to-4-month old lambs (initial BW: $15.8 \mathrm{~kg}$ $\pm 1.4 \mathrm{~kg}$ ) were used. Eight lambs were initially slaughtered to serve as the reference for initial body weight composition. The remaining 24 animals were placed in a randomized block with three treatments and eight replications. Each one of the eight experimental blocks consisted initially of three $15 \mathrm{~kg}$ lambs to which treatments (daily supplement levels: 0.0, 1.0, and 1.5\% of body weight of a corn, soybean and minerals concentrate mixture adjusted for a daily $200 \mathrm{~g}$ BW gain at 1.5\% level) were randomly assigned. As one of the lambs reached $30 \mathrm{~kg}$ all three were slaughtered. Body composition (per kg of empty body weight - EBW), ranged from 171.59 to $145.84 \mathrm{~g}$ protein, from 0.53 to $319.00 \mathrm{~g}$ fat, and from 2,06 to 3,90 Mcal energy, for lambs from 15 to $30 \mathrm{~kg}$ EBW, respectively. Net requirements for $200 \mathrm{~g}$ BW gain/day ranged from 25.99 to $22.09 \mathrm{~g}$ protein and from 0.311 to 0.591 Mcal energy for lambs from 15 to $30 \mathrm{~kg}$ EBW, respectively. Santa Inês lambs browsing in tropical semiarid regions require more protein and less energy than lambs raised in temperate regions or kept in feedlots in tropical areas, as reported in the literature.

Key Words: caatinga, native pasture, sheep

\section{Composição corporal e exigências líquidas de proteína e energia para ganho de peso de cordeiros em pastejo}

RESUMO - Este trabalho foi realizado com o objetivo de avaliar a composição corporal em gordura, proteína e energia e as exigências nutricionais para ganho de peso em cordeiros em sistema de pastejo na região semi-árida. Foram utilizados 32 cordeiros Santa Inês, castrados, com peso inicial de 15,8 kg \pm 1,4 kg e idade variando entre 3 e 4 meses. Desses animais, oito cordeiros foram abatidos no início do experimento, como animais-referência, para determinação da composição corporal inicial na metodologia do abate comparativo. Os 24 animais remanescentes foram utilizados em delineamento em blocos casualizados, com três tratamentos e oito blocos. Cada um dos oito blocos experimentais foi composto inicialmente de três cordeiros de $15 \mathrm{~kg}$, aos quais foram aplicados os tratamentos (0,0, 1,0 e 1,5\% do peso vivo do animal de suplementação diária com mistura concentrada composta de fubá de milho, farelo de soja e mistura mineral, ajustada para ganho de peso médio diário estimado em 200 g) aleatoriamente designados. Quando um dos animais de cada lote atingiu $30 \mathrm{~kg}$ de peso, os três animais do lote foram abatidos. Os valores estimados de composição corporal variaram de 171,59 a 145,84 g de proteína/kg de peso do corpo vazio (PCV); 0,53 a 319 g de gordura/kg de PCV; e 2,06 a 3,90 Mcal/kg de PCV para animais de 15 a $30 \mathrm{~kg}$ de PCV. As exigências líquidas para ganho médio de $200 \mathrm{~g} /$ dia variaram de 25,99 a 22,09 g de proteína e de 0,311 a 0,591 Mcal de energia para animais de 15 a $30 \mathrm{~kg}$ de PV, respectivamente. Cordeiros Santa Inês em pastejo na região semiárida necessitam de mais proteína e menos energia que cordeiros confinados em regiões temperadas ou confinados em áreas tropicais como reportado na literatura.

Palavras-chave: caatinga, ovinos, pasto nativo

\section{Introduction}

It is known that animal nutrition is fundamental to lamb meat production. However, the adopted nutritional requirements for lambs in Brazil are reproduced from other countries or extrapolated from other species. Although Brazil has its own climate and animal differentiation, the recommendations of the International Committees on animal 
nutrition have not yet been adapted.211 Researchers are studying the nutritional requirements of ruminants for the specific conditions of tropical semi-arid regions (Geraseev et al 2000; Silva et al. 2003; Gonzaga Neto et al., 2005; Silva et al.2007). Also, it is important to complement the knowledge in terms of feeding behavior, bromatological composition of the forage and other items consumed by the animals, and of feed use efficiency to develop low cost and efficient diets.

Protein has a fundamental role in the animal organism. It takes part in tissue formation and maintenance, muscle contraction, nutrient transport and hormone and enzyme synthesis. Prolonged protein deficiency may cause volume reduction in blood, liver and muscles that in turn may harm animal immunity and food use efficiency, due to alterations in the rumen functions (Santos, 2006).

Excess protein may cause energy and economic loss. Energy content is considered critical when adjusting diets to ruminants, especially in fiber-rich ones. This means that energy availability is regulated by an adequate supply of protein in the diet. Energy deficiency delays puberty and decreases animal growth, fertility, body weight gain, milk production and other productive parameters (Resende et al., 2006).

Nutritional requirements depend on age, body size, growth rate, lactation period, hair or wool growth, muscle activity, other n211utrient availability and environmental factors, such as temperature, air humidity, solar radiation and wind speed (NRC, 1985).

The lack of data on protein and energy requirements for sheep in tropical conditions has forced researchers in that area to develop appropriate tables of nutrient requirements. Also, when there is information on sheep nutritional requirements in Brazil, it is not useful for animals under rangeland conditions, so that further studies are necessary. Thus, the objective this study was to evaluate the body composition and nutritional requirements of protein and energy of Santa Inês lambs under rangeland plus supplementation feeding regime in the semiarid region of Northeast Brazil.

\section{Material and Methods}

The study took place in the Experimental Station of the Universidade Federal de Campina Grande, in Patos, Paraíba, located within the Sertão micro-region. The local climate is classified as hot and dry, with well defined dry (from June to December) and rainy (from January to May) seasons, with $750 \mathrm{~mm}$ mean annual rainfall. Air moisture, and maximum and minimum temperatures during the experimental period were $60 \%, 37{ }^{\circ} \mathrm{C}$ and $21{ }^{\circ} \mathrm{C}$, respectively.

Data were collected from 32 Santa Inês castrated, 3-to-4-month old lambs, with an initial mean body weight of $(15.8 \pm 1.4) \mathrm{kg}$. Eight of them were considered as the "Reference Animals" according to the comparative slaughtering methodology, and were slaughtered at the beginning of the experiment to establish the initial body composition. The remaining lambs were divided into three groups, each one fed one level of concentrate supplementation $(0.0 \%, 1.0 \%$ and $1.5 \%$ live body weight). Then, blocks of three lambs, one for each supplementation level, were formed when they simultaneously reached approximately $15 \mathrm{~kg}$ of body weight. When one lamb in a group reached $30 \mathrm{~kg}$ they were all slaughtered.

The eight animals had free access to water and to a 2 ha area of native herbaceous pasture with scattered bushes and trees, enriched with buffel grass (Cenchrus ciliaris L. cv. Biloela) from 7 a.m. to 4 p.m. They were gathered and kept in individual $1 \mathrm{~m}^{2}$ stalls from 4 p.m. to 7 a.m. In the stalls, the lambs received water ad libitum and the corresponding concentrate supplementation treatment. The lambs were weighed every 14 days. The first 21 preexperimental days were used for animal adaptation to the new management and feeding practices and to the enriched native pasture. The remaining 56 days were used for data collection.

The concentrate mixture was consisted of $40.4 \%$ corn meal, $56.6 \%$ soybean meal, and $3.0 \%$ mineral mixture (Ca, P, Na, Zn, Cu, Mn, Mg Co, I, and Se: 260, 136, 351, 8.40, $1.10,7.60,6.00,0.24,0.14$ and $0.08 \mathrm{mg} / \mathrm{kg}$ concentrate, respectively) (Table 1 ). The $1.5 \%$ daily supplementation level was expected to comply with the AFRC (1995) recommendations for crude protein and metabolizable energy in order to result in a daily body weight gain of 200 g/animal.

Forage samples were obtained by successive random throws of a $(1.00 \times 0.25) \mathrm{m}^{2}$ iron frame (Araújo Filho etal., 1986) in the field, followed by separation of grasses and herbs

Table 1 - Nutritional composition of the ingredients used in the experimental diets

\begin{tabular}{lrrrr}
\hline Ingredient & Grasses & $\begin{array}{c}\text { Dycotyledonous } \\
\text { herbs }\end{array}$ & $\begin{array}{r}\text { Corn } \\
\text { meal }\end{array}$ & $\begin{array}{r}\text { Soybean } \\
\text { meal }\end{array}$ \\
\hline $\begin{array}{l}\text { Dry matter (\%) } \\
\text { Metabolizable }\end{array}$ & 66.54 & 50.63 & 90.02 & 91.64 \\
$\begin{array}{l}\text { energy (Kcal/kg) } \\
\text { Crude protein (\%) }\end{array}$ & 4479 & 4418 & 5670 & 5310 \\
$\begin{array}{l}\text { Neutral detergent } \\
\text { fiber (\%) }\end{array}$ & 79.08 & 9.22 & 9.73 & 45.96 \\
Acid detergent fiber (\%) & 49.32 & 68.31 & 9.00 & 7.90 \\
Ash (\%) & 7.30 & 45.75 & 4.01 & 3.82 \\
& & 6.70 & 6.02 & 7.27 \\
\hline
\end{tabular}

R. Bras. Zootec., v.39, n.1, p.210-216, 2010 
collected inside the frame perimeter. Grass and herb samples were dried, ground and analyzed.

Feed intake was estimated with the combined use of hydroxiphenilpropane - LIPE external indicator (determination of feces production), undigestible-Neutra detergent fiber internal indicator (estimation of the undigestible fraction of diet), and the equation recommended by Forbes (1995).

Weighing (body weight at slaughtering) and slaughtering occurred after a 16-hour and 12-hour fasting period of food and water, respectively. The animals were desensitized by cudgeling them on the head, and killed by cutting the carotid artery and jugular vein. The blood was collected, the gastrointestinal tract removed and weighed in order to determine the empty body weight. Then, the blood, entrails, skin, head, feet, and carcass of each animal were frozen, ribbon sawed into pieces, ground and homogenized altogether. Samples (500 g) were stored in a freezer before analyses.

Analyses were performed in $50 \mathrm{~g}$ sub-samples after defrosting in a microwave oven (three one-minute periods, five minutes apart from each other to avoid overheating). Then the samples were fragmented with a glass stick, and dried in a forced air stove at $55^{\circ} \mathrm{C}$ for 4 hours. The samples were then ground in a ball mill and kept in hermetically closed plastic containers for later dry matter, crude protein, fat, energy, and ash content determination (Silva and Queiroz, 2002).

Body protein, fat and energy were estimated using regression equations that correlated the logarithm of the nutrient quantity in the empty body (Y) and the empty body weight (X) (ARC, 1980). The body composition of the weight gain was determined by the comparative slaughtering method (ARC, 1980) that considers the difference between the total of each nutrient in the empty body of the animals slaughtered at $30 \mathrm{~kg}$ and in the empty body of the reference 15-kg lambs.
Nutrient retention in the animal body was determined based on the concentration of each nutrient in the analyzed samples. Body composition (quantity of a nutrient / kg of empty body weight) was estimated from allometric regressions calculated from these nutrient retention data, according to the ARC.

The empty body weight gain was calculated by deriving the regression equation correlating the logarithm of the nutrient quantity in the empty body $(\mathrm{Y})$ and the empty body weight $(\mathrm{X})$, resulting in $\mathrm{Y}^{\prime}=\mathrm{b}^{*} 10^{\mathrm{a}} * \mathrm{X}^{(\mathrm{b}-1)}$, according to the methodology described by ARC (1980).

Analysis of variance used the PROC ANOVA, PROC REG sub-routine in the SAS software (SAS, 1999). Regression analyses were made on the model $\mathrm{Y}=\mathrm{a}+\mathrm{b} * \mathrm{X}$.

\section{Results and Discussion}

Dry matter, crude protein and neutral detergent fiber daily intake, according to the NDFi method (Berchielli et al., 2000), was $60.70,3.99$ and $43.20 \mathrm{~g} / \mathrm{kg}^{0.75}$ for the $0 \%$ concentrate supplemented lambs, $66.40,10.19$ and $38.60 \mathrm{~g} / \mathrm{kg}^{0.75}$ for the $1 \%$ concentrate supplemented lambs, and 75.30, 15.9 and $35.50 \mathrm{~g} / \mathrm{kg}^{0,75}$ for the $1.5 \%$ concentrate supplemented lambs. Mean body weight gain was 77.00, 134.00 and $190.00 \mathrm{~g} /$ day, and feed conversion was 10.2, 5.0 and 3.5, for $0.0,1.0$ and 1.5 concentrate supplemented lambs, respectively (Table 2 ).

Increases in the supplementation levels and empty body weight values affected positively dry matter content in the empty body weight from 31.15 to 35.18 to $36.19 \%$. However, the crude protein content in the empty body weight decreased with supplementation $(\mathrm{P}<0.05)$. This can be explained by the higher body weight gain and fat deposition with the increase in supplementation level. Compared to the reference animals, the fat content decreased to half or remained similar for, respectively, 0 or $1 \%$ concentrate supplemented lambs, indicating that the non-

Table 2 - Means for body weight and empty body weight and composition of Santa Inês lambs in Caatinga (tropical thorn forest) rangeland and fed three concentrate levels

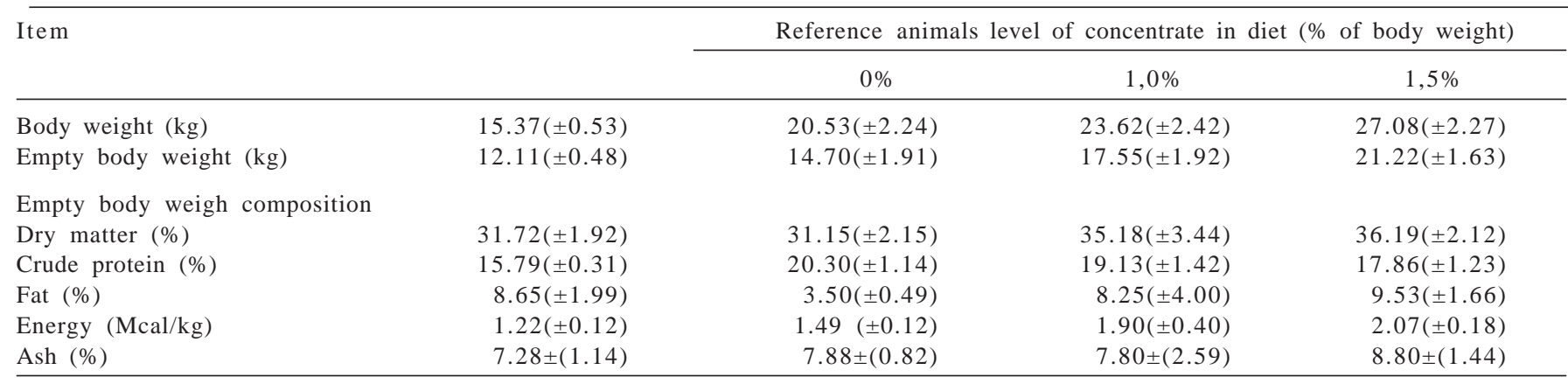


supplemented diet was not enough for animal maintenance. Silva et al. (2007) reported fat content values ranging from 8.80 to $13.80 \%$ in Santa Inês lambs. The low fat content values found in the present study were probably due to the higher energy demand these animals require for browsing, as reported by Arnold et al. (1998).

In this study, the energy content in the empty body weight ranged from 1.49 to $2.07 \mathrm{Mcal} / \mathrm{kg}$. There are reports of energy contents ranging from 1.74 to $2.27 \mathrm{Mcal} / \mathrm{kg}$ in Morada Nova lambs (Gonzaga Neto et al., 2005) and from 1.72 to $2.64 \mathrm{Mcal} / \mathrm{kg}$ in Santa Inês confined lambs (Silva et al., 2007).

Regression equations were used to estimate the empty body weight from the body weight data, and crude protein, fat or crude energy quantities in the empty body from the empty body weight data (Table 3 ). The high values of the coefficients of determination resulted from the low dispersion of the data and the high adjustment level of the regression equations. These regression equations were used to calculate the data (Table 4), which are values for crude protein, fat and crude energy contents for specific values of body weight and the corresponding empty body weight.

The crude protein concentration decreased from 212.00 to $180.00 \mathrm{~g} / \mathrm{kg}$ of empty body weight when the body weight increased from 15 to $30 \mathrm{~kg}$. This corresponds to the same trend observed by Silva et al. (2007) and Gonzaga Neto et al. (2005). However, the crude protein concentration in the empty body weight in the present study was $35 \%$ higher than the concentrations found in confined 20-to-30 kg body weight Santa Inês lambs (Silva et al., 2007) and 10\% higher than the values reported for 15-25 kg body weight Morada Nova lambs (Gonzaga Neto et al., 2005).

The fat contents in 15-to-30-kg (body weight) lambs of the present study ranged from 17.3 to $103.2 \mathrm{~g} / \mathrm{kg}$ empty body weight, lower than the 91-to-106 g/kg empty body weight values reported for 20-to-30 kg (body weight) Santa Inês lambs by Silva et al. (2001), and the 94-to-172 g/kg empty body weight values obtained from 15 -to-30 kg Texel $\times$ Santa Inês lambs by Oliveira et al. (2004). The high crude protein and low fat concentration in the empty body weight were probably a result of the higher energy requirement due to browsing and the consequent reduction in fat accumulation.

Energy content in the empty body increased with body weight, the same trend reported by Oliveira et al. (2004) and Gonzaga Neto et al. (2005), although the values in the present browsing regime study were lower than the 1805-to$2338 \mathrm{Mcal} / \mathrm{kg}$ values observed in confined 15-to-25-kg lambs.

Deriving the allometric decimal logarithm equations of the body composition (Table 3) in crude protein, fat and energy, according to the empty body weight values, resulted in equations to predict crude protein, fat and energy contents (Table 4). From these equations the values for

Table 3 - Regression equations of body weight $\left(\mathrm{X}_{1}\right)$ to empty body weight $\left(\mathrm{Y}_{1}\right)$ and of log empty body weight $\left(\mathrm{X}_{2}\right)$ to log empty body crude protein $\left(\mathrm{Y}_{2}\right)$, fat $\left(\mathrm{Y}_{3}\right)$ and energy $\left(\mathrm{Y}_{4}\right)$

\begin{tabular}{llll}
\hline Variables & \multicolumn{1}{c}{ Regression equation } & $\mathrm{R}^{2}$ & $\mathrm{CV}(\%)$ \\
\hline Empty body weight $(\mathrm{kg})$ & $\mathrm{Y}_{1}=-3.4699+0.8966 \mathrm{X}_{1}{ }^{*}$ & 0.95 & 3.74 \\
Protein $(\mathrm{g})$ & $\log \mathrm{Y}_{2}=2.5166+0.8095 \log \mathrm{X}_{2}{ }^{* *}$ & 0.79 & 1.74 \\
Fat $(\mathrm{g})$ & $\log \mathrm{Y}_{3}=-0.8542+3.0938 \operatorname{logX_{2}**}$ & 0.79 & 5.71 \\
Energy $(\mathrm{kcal} / \mathrm{kg})$ & $\log _{4}=-0.6785+1.7497 \log \mathrm{X}_{2}^{* *}$ & 0.87 & 5.75 \\
\hline
\end{tabular}

* or **: 5 or $1 \%$ significance level by the Student " $\mathrm{t}$ " test.

Table 4 - Crude protein, fat and energy concentration estimates according to empty body weight (EBW) or gain in EBW of Santa Inês lambs under Caatinga conditions

\begin{tabular}{|c|c|c|c|c|}
\hline Body weight (kg) & EBW (kg) & Crude protein ${ }^{1}$ (g/kg of EBW) & Fat $^{2}(\mathrm{~g} / \mathrm{kg}$ of EBW) & Energy $^{3}(\mathrm{Mcal} / \mathrm{kg}$ of EBW) \\
\hline 15 & 9.97 & 212.0 & 17.3 & 1.176 \\
\hline 20 & 14.46 & 197.5 & 37.6 & 1.554 \\
\hline 25 & 18.94 & 187.6 & 66.2 & 1.902 \\
\hline 30 & 23.42 & 180.2 & 103.2 & 2.230 \\
\hline & & Crude protein (g/kg of EBW gain) & Fat (g/kg of EBW gain) & Energy (g/kg of EBW gain) \\
\hline 15 & 9.97 & 171.59 & 53 & 2.06 \\
\hline 20 & 14.46 & 159.88 & 116 & 2.72 \\
\hline 25 & 18.94 & 151.86 & 205 & 3.33 \\
\hline 30 & 23.42 & 145.84 & 319 & 3.90 \\
\hline
\end{tabular}

${ }^{1}$ Crude protein $=265.9603238 * \mathrm{EBW}^{-0.1905}$

${ }^{2} \mathrm{Fat}=0.432804966 * \mathrm{EBW}^{2.0938}$.

${ }^{3}$ Energy $=0.3668 * \mathrm{EBW}^{0.7497}$. 
crude protein, fat and energy deposition/kg gain in empty body weight were estimated. Crude protein deposition in the empty body weight decreased linearly in lambs from 15 to $30 \mathrm{~kg}$ body weight, while fat and crude energy deposition increased. The linear effect for crude protein deposition in the present study was similar to that reported elsewhere (ARC, 1980, AFRC, 1995; Silva et al., 2007).

Fat deposition/kg gain in empty body weight ranged from 53 to $319 \mathrm{~g} / \mathrm{kg}$. Silva et al. (2001) reported values from 193 to $261 \mathrm{~g} / \mathrm{kg}$ in confined Santa Inês lambs with 20-to$30 \mathrm{~kg}$ body weight. Energy level increased 90\% (Table 4) when lamb weight increased from 15 to $30 \mathrm{~kg}$ body weight due to the corresponding fat accumulation. The energy concentration in gain of empty body weight in lambs within this weight interval, reported by Silva et al. (2001), ranged from 2.748 to $4.336 \mathrm{Mcal} / \mathrm{kg}$, a $58 \%$ increase. This 90 -to- $58 \%$ dissimilarity may be due to differences in climate and browsing-confinement regimes observed during the present study and that by Silva et al. (2001). However, Oliveira et al. (2004) studied four Texel × Santa Inês genetic groups under confinement regime and found energy concentrations similar (from 2.08 to $2.54 \mathrm{Mcal} / \mathrm{kg}$ of body weight) and unexpectedly lower (from 2.69 to $2.82 \mathrm{Mcal} / \mathrm{kg}$ of body weight) than the values found in 15-to-20 kg lambs and in 25-to-30-kg lambs from the present study, respectively. This was probably a result of the Texel breed or of the temperate climate observed in the region where those authors carried out their study that increased the energy demand of the Texel $\times$ Santa Inês lambs.

Based on the protein and energy quantities in the empty body weight (Table 4), net protein and energy requirements/kg gain in empty body weight, respectively $\mathrm{NP}_{\mathrm{g}}$ and $\mathrm{NE}_{\mathrm{g}}$ (Table 5), were estimated by dividing the concentration of protein or energy $/ \mathrm{kg}$ gain in empty body weight by 1.32 (i.e.: body weight : empty body weight ratio). Metabolizable protein requirements (Table 5) considered the use efficiency factors (1.00 for maintenance and 0.59 for growth) mentioned by AFRC (1995).

Few differences were observed in $\mathrm{NP}_{\mathrm{g}}$ in the 15 -to- $30 \mathrm{~kg}$ lambs. For a daily $200 \mathrm{~g}$ body weight gain, it ranged from 25.99 to $22.09 \mathrm{~g}$ in the present study, and Silva et al. (2007) reported values from 23.68 to $22.50 \mathrm{~g}$ for confined Santa Inês lambs. Resende et al. (2005), in a review of data published in Brazil, detected that NPg for hair lambs was slightly higher than for wool lambs.

Table 5 - Daily net and metabolizable protein (g/animal) and energy requirements (Mcal) of Santa Inês lambs

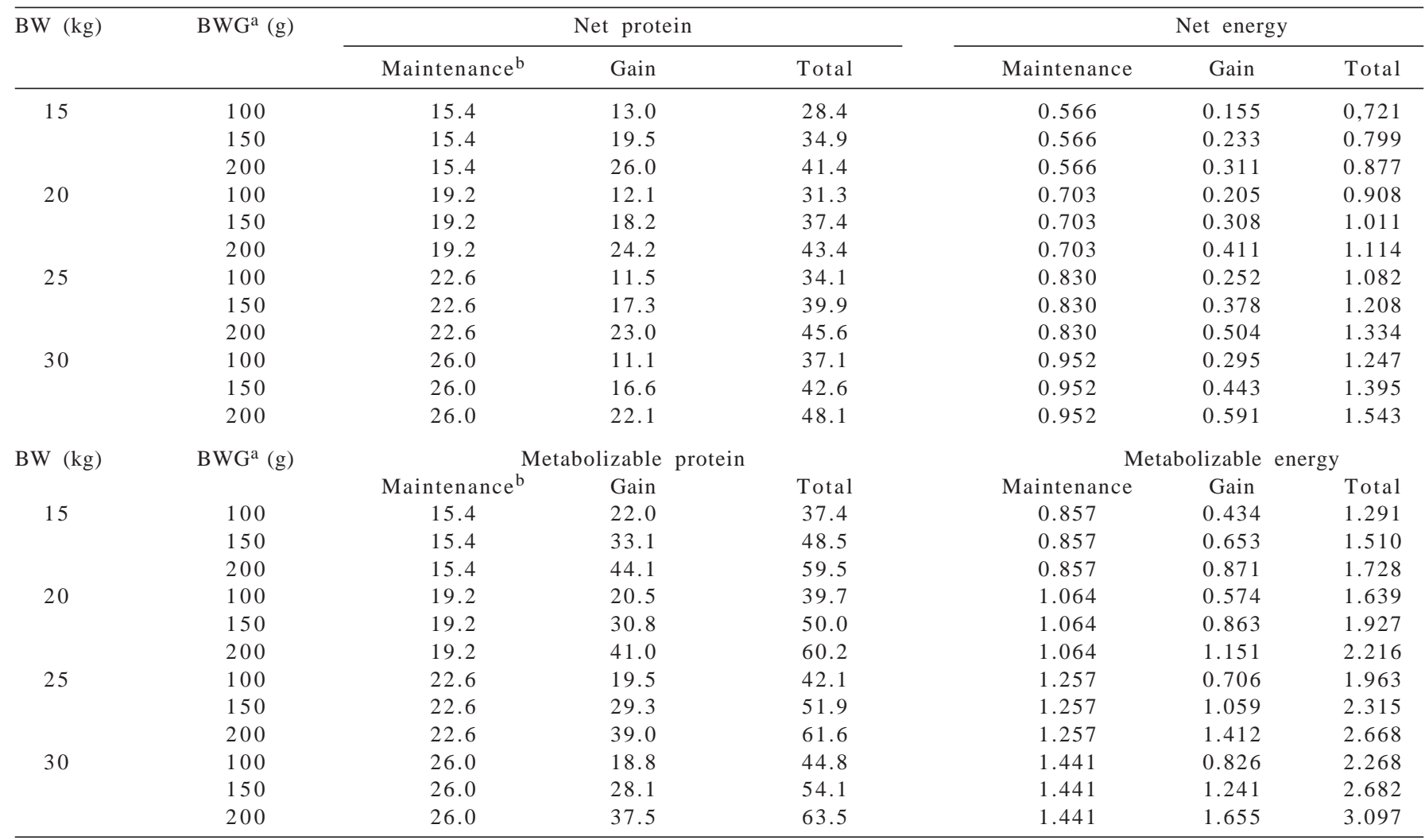

a Body weight gain

b Net protein and energy requirements for maintenance according to Silva et al. (2003).

$\mathrm{K}_{\mathrm{f}}=$ use efficiency of MP for growth $=0.59$ (AFRC, 1993)

$\mathrm{K}_{\mathrm{m}}=$ use efficiency of ME for maintenance $=0.35 . \mathrm{q}_{\mathrm{m}}+0.503(\mathrm{ARC}, 1980)$

$\mathrm{K}_{\mathrm{g}}=$ use efficiency of ME for growth $=0.78 \mathrm{q}_{\mathrm{m}}+0.006$ (ARC, 1980)

$\mathrm{q}_{\mathrm{m}}=0.45$ (Silva, et al., 2003) 
According to the NRC (1985) methodology, daily deposition of protein in half-mature lambs, in a daily 200 g-body weight gain regimen, was 38,35 or 33 g in 20 , 25 or $30 \mathrm{~kg}$ lambs, respectively. These values, using the efficiency coefficient of utilization of metabolizable protein for gain $\mathrm{K}_{\mathrm{g}}=0.59$ (ARC, 1980), are equivalent to 64, 59 or $56 \mathrm{~g}$. However, the AFRC (1995) recommendation is 95 or $100 \mathrm{~g}$ metabolizable protein/200 g body weight gain in 20 - or 30-kg lambs, respectively. The protein requirements for weight gain were shown to be higher for lambs under rangeland than feedlot conditions. They also were higher than the values recommended by AFRC (1995) for wool lambs raised in temperate regions.

Energy requirements in the diet (Table 5) were estimated using the equation of use efficiency of metabolizable energy for body weight gain $\left(\mathrm{K}_{\mathrm{g}}=0.78 \mathrm{q}_{\mathrm{m}}+0.006\right)$ (ARC, 1980), adopting the metabolizability $\left(\mathrm{q}_{\mathrm{m}}=0.45\right)$ used by Silva et al. (2001).

There was little difference in protein requirements for 15-to-30 kg lambs, while the net energy requirements almost doubled in this same range of body weight. According to ARC (1980), when the animal enters maturity, energy requirement increases with body weight.

Lambs with 15-to-30 kg body weight, under a daily 200 g body weight gain regimen, showed $\mathrm{NE}_{\mathrm{g}}$ ranging from 0.311 to $0.591 \mathrm{Mcal} /$ animal/day. Metabolizable energy requirements were from 0.574 to $0.826 \mathrm{Mcal} / \mathrm{animal} /$ day in 20-to-30 kg lambs in a daily body weight gain regimen of $100 \mathrm{~g}$, and from 1.151 to $1.655 \mathrm{Mcal} /$ animal/day in a daily body weight gain regimen of $200 \mathrm{~g}$. These values were similar to those found by Silva et al. (2001) for Santa Inês and Ideal $\times$ Ile de France lambs. The data on the energy requirement observed in the present study suggest that lambs under rangeland conditions in semiarid region are less energy demanding than lambs raised in temperate regions or kept in feedlots in tropical regions reported in the literature. This result opposes the normally accepted concept that animals under browsing regimen spend more energy than under feedlot regimen. Probably, much of the available energy in tropic semiarid region is not actually used to maintain body temperature. Further studies are necessary to determine energy requirements for maintenance which probably will lead to very interesting results.

\section{Conclusions}

The protein requirement decreased and the energy requirement increased with the increase in body weight. Santa Inês lambs under rangeland conditions in semiarid regions demand more protein and less energy than the standard levels for animals raised in temperate regions or kept in feedlots in tropical regions reported in the literature.

\section{Acknowledgements}

The authors are grateful to the funds allocated to this project by the CNPq, a Brazilian government development agency.

\section{References}

AGRICULTURAL AND FOOD RESEARCH COUNCIL - AFRC. Energy and protein requirements of ruminants. An ddvisory manual prepared by the AFRC Technical Committee on Responses to Nutrients. Wallingford: CAB International, 1995. 159p.

ARAÚJO FILHO, J.A.; VALE, L.V.; ARAÚJO NETO, R.B. et al. Dimensões de parcelas para amostragem do estrato herbáceo da caatinga raleada. In: REUNIÃO ANUAL DA SOCIEDADE BRASILEIRA DE ZOOTECNIA, 23., 1986, Campo Grande. Anais... Campo Grande: Sociedade Brasileira de Zootecnia, 1986. p.268.

AGRICULTURAL RESEARCH COUNCIL - ARC. The nutrient requirements of ruminant livestock. Farnham Royal: Commonwealth Agricultural Bureaux, 1980. 351p.

ARNOLD, A.M.; MEYER, H.H. Effect of gender, time of castration, genotype and feeding regimen on lamb growth and carcass fatness. Journal of Animal Science, v.66, p.2468-2479, 1988.

BERCHIELLI, T.T.; ANDRADE, P.; FURLAN, C.L. Evaluation of internal indicators on digestibility trials. Revista Brasileira de Zootecnia, v.29, p.830-833, 2000.

FORBES, J.M. Voluntary food intake and diet selection in farm animals. Wallington: CAB, 1995. 532p.

GERASEEV, L.C.; PEREZ, J.R.O.; RESENDE, K.T. et al. Body composition and $\mathrm{Ca}$ and $\mathrm{P}$ nutritional requirements for weight gain and maintenance of Santa Inês 15-to-25-kg lambs. Revista Brasileira de Zootecnia, v.29, p.261-268, 2000.

GONZAGA NETO, S.; SILVA SOBRINHO, A.G.; RESENDE, K.T. et al. Body composition and protein and energy requirements of Morada Nova lambs. Revista Brasileira de Zootecnia, v.34, p.1-11, 2005.

NATIONAL RESEARCH COUNCIL - NRC. Nutrient requirements of domestic animals: nutrient requirements of sheep. Washington, D.C.: NRC, 1985. 91p.

OLIVEIRA, A.N; PÉRES, J.R.O.; CARVALHO, P.A. et al. Body composition and net protein and energy requirements of four genetic groups of lambs. Revista Ciência Agrotécnica, v.28, p.1169-1176, 2004.

RESENDE, K.T; FERNANDES, M.H.M.R.; TEIXEIRA, I.A.M.A. Nutrient requirements of goat and sheep. In: REUNIÃO ANUAL DA SOCIEDADE BRASILEIRA DE ZOOTECNIA, 42., 2005, Goiânia. Anais... Goiânia: Sociedade Brasileira de Zootecnia, 2005, p.114-135.

RESENDE, K.T.; TEIXEIRA, I.A.M.A; FERNANDES, M.H.M.R. Metabolismo e energia. In: BERCHIELLI, T.T; PIRES, A.V.; OLIVEIRA, S.G. (Eds.) Nutrição de ruminantes. São Paulo: FAPESP/FUNEP, 2006. p.311-331.

SANTOS, F.A.P. Metabolismo de proteínas. In: BERCHIELLI, T.T; PIRES, A.V.; OLIVEIRA, S.G. Nutrição de ruminantes. São Paulo: FAPESP/FUNEP, 2006. p.255-284.

SILVA, A.M.A.; SILVA SOBRINHO, A.G.; TRINDADE, I.A.C.M. et al. Net requirement of energy for weight gain of growing lambs. In: REUNIÃO ANUAL DA SOCIEDADE BRASILEIRA DE 
Zootecnia, 38., 2001, Piracicaba. Anais... Piracicaba: Sociedade Brasileira de Zootecnia, 2001. p.1258-1259.

SILVA, A.M.A.; SILVA SOBRINHO, A.G.; TRINDADE, I.A.C.M. et al. Net requirements of protein and energy for maintenance of wool and hair lambs in a tropical region. Small Ruminant Research, v.49, p.165-171, 2003.

SILVA, A.M.A.; SILVA SOBRINHO, A.G.; TRINDADE, I.A.C.M. et al. Net and metabolizable protein requirements for body weight gain in hair and wool lambs. Small Ruminant Research, v.67, p.192-198, 2007.

SILVA, D.J.; QUEIROZ, A.C. Food analysis: chemical and biological methods. Third edition, UFV, Viçosa, MG, 2002. $235 p$.

STATISTICAL ANALYSIS SYSTEMS - SAS. User's guide: statistics. Companion for the Microsoft Windows Environment, version 6.12. Cary: SAS Institute, 1999. (CD-ROM). 